\title{
DYNAMICS
}

\section{Boshnjaks. In other words: Jihad vs. McWorld and other theories...}

\author{
Justyna Pilarska, justine_p@op.pl
}

\begin{abstract}
:
The Ottoman invasion of the Balkans that began in the 14th century led to an imbalance in the process of self-identification among the Bosnian people, having crucial influence on the process of establishing their sense of belonging, identification and national awareness. It particularly influenced the process of conceptualizing the cultural identity of Boshnjaks, whose ancestors converted to Islam and changed the ethnic and religious landscape of Balkans to a large extent. The author focuses on the political and social factors determining the shape of Bosnian identity, its origin and historical circumstances which influenced not only identification processes but also the course of the conflict in the Balkans between 1992 and 1995. This paper also provides data on many controversial facts regarding influences of Islamic radicals on Bosnian society before and after the fall of Yugoslavia. On the basis of social and historical analysis the author indicates that contemporary theories on cultural origin of conflicts, reduced to the dichotomy Jihad vs. McWorld are not applicable in the case of the unique, multicultural identity of Bosnian Muslims.
\end{abstract}

Key words: the Balkans, Bosnia, Islam in Europe, Islamicization, cultural identity, multiculturalism, Yugoslavia, Muslims.

B.R. Barber, head of the Walt Whitman Center for the Culture and Politics of Democracy at Rutgers University, former advisor to the president B. Clinton, in his book "Jihad vs. McWorld" made attempts to prove that globalization processes (McWorld) and separatist tendencies ( Jihad) constitute a specific feedback affecting one another, motivating the social life figures to active participation (Barber 1996).

Are these the same forces that determined the course of conflict (called "civil") that look place in Bosnia? The question is well justified taking into consideration the involvement of the Afghan squad, that in this context was rather significant, nevertheless it paradoxically 
contributed to the failure of militant Islam, as it found no well received ground among secular, multicultural Bosnian Muslims.

In the aspect of current social disturbances caused by assimilated descendants of Islamic immigrants in the countries of Western Europe it is worth taking a closer look at Muslims that have constituted a natural element in the ethnic landscape in Europe since the 14th century. Perhaps it will allow us to answer how they find themselves in this sort of "clash of civilizations" theory, as suggested by S.P. Huntington (Huntington 1996).

Bosnia $^{1}$ is a curiosity on the political and cultural map of Europe and it may be perceived from the perspective of changes, both positive and destabilizing in the region. It is probably the only sphere of cultural self identification in the Islamic world that allows the citizen to be a Muslim in the category of nationality ${ }^{2}$ and atheist in respect of religious status [sic!]. On the other hand, it is the European area which in political and sociological analysis appears to be perceived as a tinderbox taking into consideration religious and ethnic factors. Hence, it is worth asking the question what kind of living conditions exist in this country for Boshnjaks? How do they find their Lebensraum and Volksgeist there, bearing in mind, that only Muslims define themselves as Boshnjaks, whereas Serbs from Bosnia call themselves Bosnian Serbs and Croats being citizens of Bosnia prefer to refer to themselves as Bosnian Croats.

The very term Bosnia is a geopolitical notion, having its first mention in $958 \mathrm{AD}$ as mentioned by Constantine VII Porphyrogenitus (Byzantine emperor), De Administrando Imperio (Malcolm 1994, pp. 6-7). In 1991, on the eve of the outbreak of war, Bosnia was inhabited by over 4364 million people, of which Bosniacs ${ }^{3}$ constituted 43,6\%, Serbs 31,4\%, Croats 17,3\% with the remaining 5,5\% referring to themselves as Yugoslavs (Čuvalo 2007, p. 138). Despite the dramatic period of nearly fratricidal fights, mass murders, ethnic cleansing, forced resettlements and emigration, Bosnia in 2010 is still inhabited by three major nationalities, i.e., Boshnjaks, Croats and Serbs, however the geo- and demographical structure has significantly changed. The Croat-Muslim Federation ( $51 \%$ of the Bosnian territory) is inhabited by Croats and Boshnjaks (48\%) whereas Bosnian Serb Republic (49\% of the territory) with the capital in Banja Luka is almost exclusively of Serbian character, as Serbs

\footnotetext{
${ }^{1}$ For the purposes of this paper I shall refer to Bosnia and Herzegovina in the shape outlined by the Dayton Accord from 1995 using the term Bosnia.

${ }^{2}$ Marshal Josip B. Tito, within the framework of constitution from 1974 awarded Muslims with the status of a nation.

3 "Bosniacs" is a notion defining citizens of Bosnia whereas "Boshnjaks" refer to Muslim Bosnians.
} 
constitute $97 \%$ of this part, if taking the entire Bosnian territory into account the proportion amounting to $37,1 \%$ (Ibrahimagić 1996, p.37). The changes within ethnic structure in Bosnia affecting population layout before the conflict and currently are presented in the following maps.

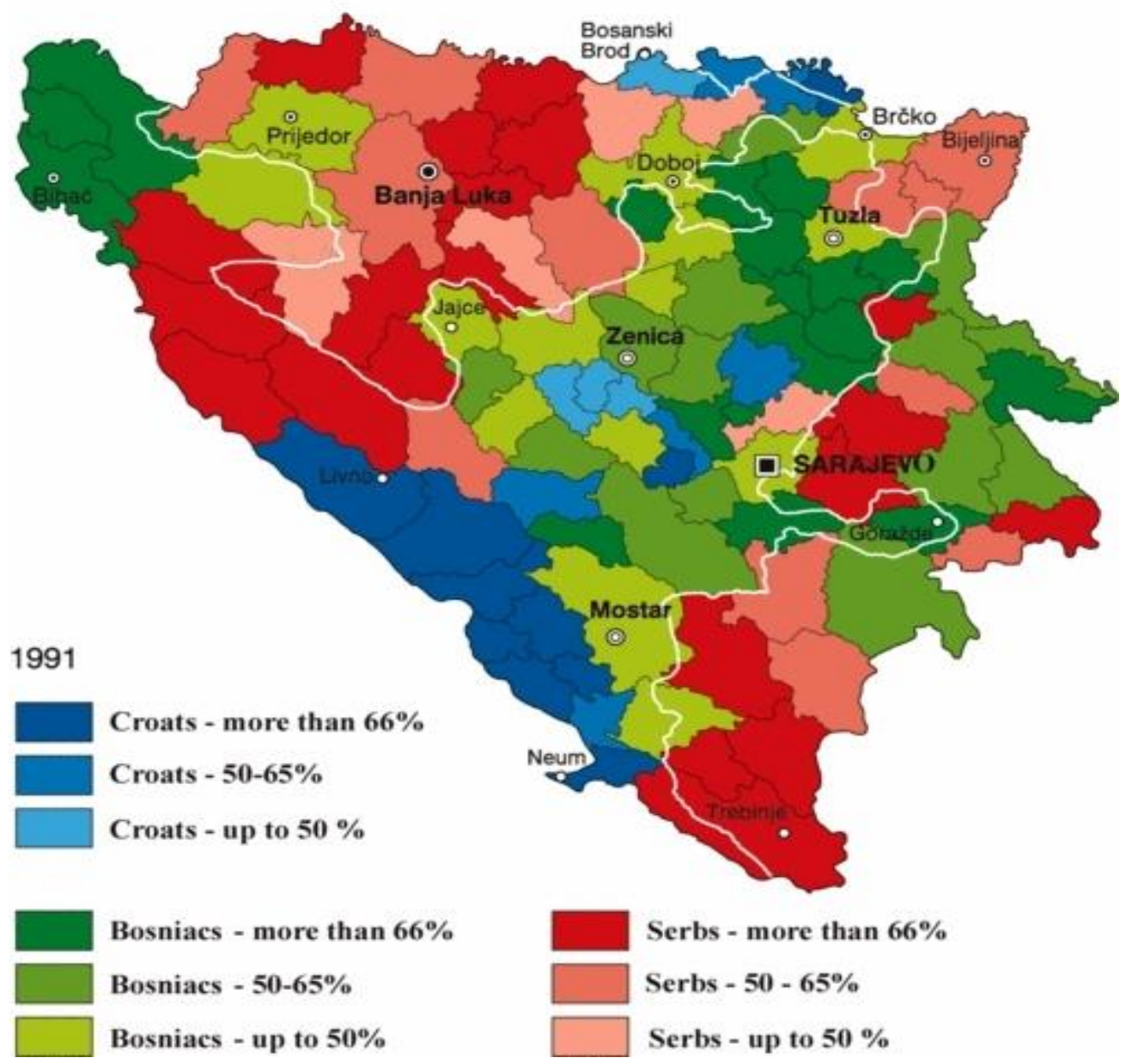

Fig. 1. Ethnic composition in Bosnia in 1991, before the war. Source: Čuvalo 2007, p. 287. 


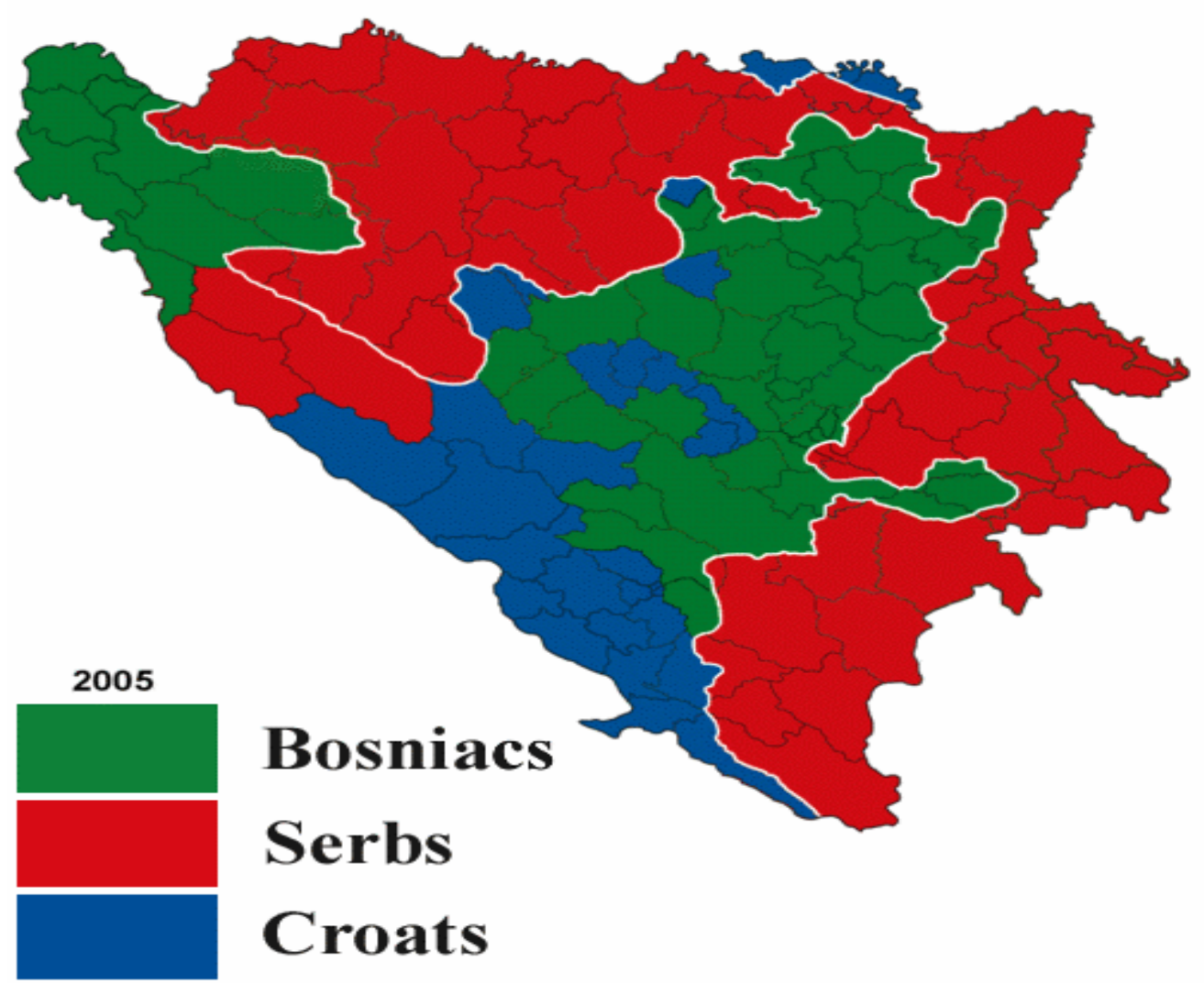

Fig. 2. Ethnic composition in Bosnia in 2005, after Dayton Peace Accord. Source: Čuvalo 2007, p. 287.

Although Slavic tribes arrived in the Balkans as early as 6-7th century, the Turkish Ottoman invasion of the Balkans was the turning point in the history of Bosnia and The Balkans that changed their cultural and political shape determining the sense of Muslim cultural identity. The Ottoman invasion of the Balkans in the 14th and the 15th centuries had interrupted the natural development of the Balkan peoples in many aspects, and as a consequence from 1463 until 1876 Bosnia was under Ottoman rule. The Islamicization of Bosnia took place incredibly dynamically, being particularly palpable from the middle of 15th century, since in 1489 Bosnia had already 29094 Christians and 6870 Muslims (Malcolm 1994, pp. 51-56). Notwithstanding the fact that the Bosnian villages became almost entirely Islamicized by the end of 18th century in the urban areas Muslims had become a majority as early as in 16th century. The Bosnian tendency to mass conversion to Islam is extremely intriguing, as it is often associated with the medieval sect of the Bosnian Church and Bogomilism movement, whose members are said to have been converting eagerly (Malcolm 1994, pp. 27-28). 
Nevertheless, the Islamic influence began even beforehand, as the capture Constantinople in 1453 was proceeded by the taking of Adrianople in 1365 by Turks, and then Serbia in 1389 (Danecki 1997, p. 47).

The Turkish/Muslim domination has left its imprint on culture and the processes of conceptualization of Bosnian identity that had taken place ceaselessly until the end of the 17th century where after The Treaty of Karlowitz in 1799, steady, consequent loss of Bosnian territory in favour of the Hapsburgs started taking place, to be lost entirely after The Berlin Treaty constituting the final act of The Congress of Berlin in 1878.

It should be also emphasized that the dwellers of 15th century Bosnia converted to Islam in rather preferable circumstances as the gentry had the right to preserve their own goods and privileges, and on the other side it was also attractive enough for peasants, considering the fact that those, who did not convert to Islam, became raja - infidels required to pay higher taxes ${ }^{4}$. Muslims managed to sustain their favourable status after abovementioned Congress of Berlin, as despite granting Austro-Hungary the right to occupy Bosnia (de facto incorporated in 1908), the Habsburgs did not abolish Muslim privileges, considering them as allies in the struggle with Serbian nationalistic movements.

Hence, taking into account the historical situation, is it justified to perceive Boshnjaks as fulfilled participants of social life, fully displaying their cultural identity, and particularly the religious one? The political factor does cast a shadow over this issue, as it implicates many problematic matters at the turn of the 20th and 21st centuries. One such controversy with Bosnian Islam is the alleged cooperation of USA Secret Service with Mujahideen, the latter believed to have been supported by the Pentagon in the 1990s in former Yugoslavia (Elsässer 2008).

Some sources put forward a hypothesis, having found evidence for such in specified documents or military sources (Elsässer 2008, p. 18, 78-79,102-103, 120-124, 230-232, 261263) that Boshnjaks supported by the Pentagon in the Balkan War between 1992-1995 were allegedly said to have taken part in terrorist attacks of 9/11 in the USA, whereas Bosnian friends of Osama bin Laden were reported to have been receiving pay slips from the CIA (Elsässer 2008, see, for example, also: Parzymies 2005, Kepel 2000).

Reflections lead to a question as to why the socialistic federation of Yugoslavia, guaranteeing civic and religious freedoms (with the latter not having been exercised too

\footnotetext{
${ }^{4}$ It was offensive term of Arabic origin used by Ottoman Turks and the Islamicized communities towards Christian lieges exercising rather limited rights and freedoms in comparison to Muslims.
} 
eagerly considering the secular nature of socialistic society of that time) did not protect Yugoslavs from the influx of the ideology of religious fanaticism? After all, Yugoslavia both constitutionally and practically granted equal rights to the citizens regardless of ethnic or religious origin. As a matter of fact, it was the Tito himself who, in the 1950s, prohibited wearing chadors and demonstrating religious identity by clothing. Notwithstanding, there have been opinions that after the death of comrade Tito "ethnic zoo was replaced by a jihad cradle" (Elsässer 2008, p. 10). Supporters of such a thesis claim that those in charge of the September 11 attack had been mastering their skills in the 1990s in the Balkans, not only directly taking part in war actions, but additionally encouraging Boshnjaks to do so (Elsässer 2008, p. 10).

During the Soviet invasion of Afghanistan (1979-1989) the Balkans were one of the crucial weapon supply lines, whereas during the conflict in the Balkans (1992-1995) the equipment and weaponry were provided despite an embargo on weapons, which was imposed by The United Nations Security Council in 1991, with ordinance to be applied in all the republics constituting Yugoslavia of that time.

Vague fundamental connotations as well as suspicions referring to the relations between Islamic radicals led to Egypt, where in 1928 a group called Young Muslims was established, being the derivative of another organization of Egyptian origin, an extremely fanatic association called Muslim Brothers set up by Hassan al-Banna (Malcolm 1994, pp. $196,208)^{5}$.

Notwithstanding, it should also be borne in mind that at the beginning of 20th century Bosnia was dominated by non-fundamental, modern Islam, having its cause in the fact that after the WW II most of the Muslims represented the pro-Yugoslav orientation (Elsässer 2008, p. 44). Perhaps it was facilitated by steadily increasing welfare in regard to a free market economy, which in consequence enhanced the popularity of the idea of a multinational state. It was reflected in the high proportion of ethnically mixed marriages in Yugoslavia between 1945 and 1990 amounting to 47\% (Čuvalo 2007, p. 241). It may be also explained by the fact that in the 1980s one in five Bosnian children was of such ethnically heterogeneous couples (Elsässer 2008, p. 45).

\footnotetext{
${ }^{5}$ The Society of Muslim Brothers is one of the most radical fundamental organizations in Islam. Their structures are based on the patterns of Dervish mystic monasteries, being originally also inspired by the structure of European political formations, I actively participate in the political field too.
} 
Significant secularization of the social life in a socialistically-spirited idea of bratstvo $i$ jedinstvo (The Brotherhood and Unity) ${ }^{6}$ was enabling harmonious intercultural dialogue within Yugoslavian nationalities, with Orthodox churches, mosques and catholic churches being visited neither frequently not in crowds. Moreover, the bonds established over the decades, as not being determined by ethnic or national origin, resulted in a rather unique phenomenon. Namely, after the war in 1992 broke out, the new Bosnian army was being joined by both Serbs and Croats protesting against nationalistic madness that seemed to have seized Yugoslavia, and in consequence those Serbs and Croats joining the Bosnian army were to fight against Serbs and Croats themselves. The sources indicate that in May of $199218 \%$ of Bosnian army soldiers were Croats with 12\% Serbs (Elsässer 2008, p. 45). This was taking place regardless of the fact that in 1995 the Arabic volunteer forces in various troops of the Bosnian army reached between 15000 to 40000 according to Serbian sources, whereas Y. Bodansky $^{7}$ claimed the number to vary between 15 000-20 000 (Elsässer 2008, pp. 70-73).

Moreover, from 1992 the cost of Balkan weaponry financed by Saudi Arabia reached $\$ 150$ million (funds taken from zakat and sadaka) (Elsässer 2008, p. 52). The weaponry was also supplied from other sources, mainly from Turkey and Iran using the communication channel in Croatia (Bellion-Jourdan 1993, p. 25).

Perhaps the idea of some sort of European perspective of jihad also constituted the grounds for establishing the El Mudžahid battalion within the 3rd Corps in the 7th Brigade, joined by fighters from abroad, since it was proved that Afghans were involved in fighting in Bosnia. Therefore, the veterans of the Afghan war (talibs and mudzaheed) significantly contributed to the religious dimension of the 1992-1995 conflict in Bosnia (Elsässer 2008, p. 134).

Nevertheless, it turned out that militant Islam did not meet with a favourable response, and it seems rather understandable taking into account the fact that the times of socialistic Yugoslavia were significantly marked by the social life structure of Ottoman origin called komşuluk, which was the tradition of common existence, being at times broken, but never rejected. Hence, it turned out that the good-neighbourly tradition of Ottoman rule, the AustroHungarian annexation, Croatian fascism and Tito's socialism managed to tighten the bonds efficiently and sufficiently enough, so that religious antagonisms became marginalized.

\footnotetext{
${ }^{6}$ The Brotherhood and Unity was one of the essential clichés and ideas of social order in Yugoslavia, however it originates from the beginning of communistic social philosophy in Balkans between 1941 and 1945.

7 The Director of the Republican Task Force on Terrorism \&Unconventional Warfare of the U.S. Congress.
} 
It is undoubtedly true that modern, non-fundamental Islam became a significant part of the Bosnian identity as early as at the beginning of 20th century, being additionally empowered by crucial pro-Yugoslavian trends, where religion was functioning solely as a private matter, taking into consideration the rather impressive loyalty to a multinational state. On the other hand, a gap in the integrity of cultural identity appeared, with religious fundamentalism having started to play an important role.

Nevertheless, the global wave of fundamentalism, or its Afghan or Saudi prophets are not the only ones to blame. Taking into account the symptoms strikingly occurring at the time of the conflict, as well as the national and religious aspirations of Muslims, such figures as A. Izetbegović ${ }^{8}$ himself should be emphasized, as his Islamic Declaration from 1970 unambiguously expressed the idea of establishing an Islamic state using fundamental tendencies putting stress on the fact that real Islam may not exist under secular circumstances (Izetbegović even dared to criticize the secular policy of Kemal Atatürk) (Huntington 1996, p.37). And despite the fact that until the 1980s - 1990s it can be justified to call the Bosnian Islam European, many authors suggest (Kepel 2000, Čuvalo 2007) that at a certain historical moment the pressure of extremists forcing their own vision of Holy War became palpable. The widely and commonly displayed attitude tolerating and accepting multiconfessionalism in Bosnia became the main antidote to such conceptions, putting up resistance predominantly.

Nevertheless, it must be remembered that still, the Balkans became the target of a financial influx from countries of salafi organizations such as Egypt or theocratic Saudi Arabia. In consequence, the economic crisis accompanying and actually predominantly causing the fall of Yugoslavia, as well as the popularity of Islamic propaganda among Boshnjaks made them think that the Yugoslavian state would no longer fulfil their aspirations, neither in religious nor national regard. Therefore, the importance of religious power increased with the concurrent depreciation of federal authorities, despite the fact that according to a public survey in 1990 Yugoslavia had only 34\% of believers, with as much as $61 \%$ of Boshnjaks having never been to a mosque [sic!] (Bellion-Jourdan 1993, p. 57) .

The fall of Yugoslavia created conditions for Muslims to separate from a state governed by "infidels", but the failure of attempts to instil jihad lies mainly in the cultural

\footnotetext{
${ }^{8}$ A. Izetbegović was the first president of the presidency of the Republic of Bosnia and Herzegovina. At the beginning of World War II, the young Izetbegović became an active member of a newly founded, already mentioned group, Young Muslims. Due to his activity and effort trying to revitalize the movement after the war, he was accused of "activities against the people" and in 1946 sentenced to three years imprisonment by the Communist regime (Čuvalo 2007, p.118).
} 
trends of modernity and democratic character of Muslim society. Perhaps the source of such a phenomenon should be looked for as early as in 1879, when Austro-Hungary, forcing the Ottoman emperor out of Bosnia, undermined Bosnian identity, leaving them the sole sphere of self identification referring to Islamicized Slavs. Nevertheless, separatist movements began to grow in popularity, as the Muslim minority also lost the established advantage over other groups as it had been dominated by Austro-Hungarian favourites, i.e. catholic Croats. Moreover, in further consequence Muslims were subordinate to Orthodox Serbs who gained power over the Kingdom of Yugoslavia between 1918 and 1941. Also, an undoubtedly important role was played by the abolition of kalifat by K. Atatürk in 1924, as it deprived Bosnian alims $^{9}$ of the only religious point of reference they had. Imbalance of religious identity was additionally shaken by the process of conceptualizing a secular, national identity based on the ties of southern Slavs ${ }^{10}$. Therefore, Muslims became the only nation deprived of its own territory, whereas secularity enabled the establishment of a multicultural community with the integrated vision of the Other ${ }^{11}$, as a natural part of social structure. On the other hand, however, some political and social processes occurring on a large, global scale began to influence the national awareness of Bosnian Muslims, which was awakening after the fall of Yugoslavia.

Despite the fact that in the Islamic world demographic explosions started to destabilize the countries of western civilization, the attempts to uproot societies from one civilization to another (instilling radical Islamic thought on European ground) turn out to be nothing but a failure. Perhaps it is the reason for recent popularity of a thesis that the wars taking place are not jihad, but borderland conflicts between communities, referred to as “communal wars" (Huntington 1996, p. 37).

Therefore, it is rather hard to accept Huntington's assumption that the source of international conflicts lies not in ideologies or economy, but in cultural differences resulting from religious divisions, which are allegedly said to have been determining the identity of nations (Huntington 1996, p. 37).

\footnotetext{
${ }^{9}$ In Arabic Ulamā' means a scholar. This notion is used with reference to educated class of Muslim legal scholars serving as authority in several fields of Islamic studies. Such person may be compared in catholic hierarchy bishop; however alim is additionally of high educational importance.

${ }^{10}$ In Serbo-Croatian Jugoslavija means southern Slav lands.

${ }^{11}$ The capital letter is intentional, by capitalizing the word I would like to point to the uniqueness and depth of an encounter with another person, with another Self; this is also a reference to Buber's philosophy of dialog and encounter (Buber 2004).
} 
Taking into account the nature of the self identity processes among Muslims of the Yugoslavian period it is also rather impossible to acknowledge Kepel's idea that finding own identity takes place in old, ready-to-use patterns of ethnical affiliation and religion (Kepel 2000, p. 65). Well indeed, it was Huntington himself writing that Muslims are Bosnians who do not go to the mosque, Serbs are Bosnians who do not go to the Orthodox Church and Croats are Bosnians who do not go to the cathedral (Huntington 1996, p. 471). And despite the fact that multi-community ceased to exist and each group constituting it began the process of identification in more general sense determining itself at the same time by religious category, it has never been a crucial factor determining the interactions in Bosnian society. It should be emphasized again in this place that until the 1990s Muslim Bosnians were a secular community, and as European Muslims they seem to have been supporting the idea of multiculturalism. Hence, it is rather difficult to look favourably on sociological or political reflections proposed by authors such as Huntington or Barber arguing that the process of Balkanization of national states is demonstrated by the dichotomy dimension of the conflict "culture vs. culture".

Taking it all into account, on the one hand it might be said there is jihad, determining from the beginning ethnic and pre-national boundaries, the bloody policy of identity as Barber calls it (Barber 1996, p. 37), but on the other hand there is one factor that mustn't be marginalized in this issue - the cultural uniqueness of Bosnia, where the policy of identity and multiculturalism constitute the strategies of free society, expressing its diversity. However, it must be emphasized, the threat appears when the memory of mutual history is neglected in favour of the propaganda exercised in Muslim media, gloomily promoting the inevitable vision of McWorld and the songs of jihad, with the identity determined by needs and desires (Barber 1996, p. 37).

In such perspective it is worth asking the question whether Bosnia can be inspired by societies composing states as USA, France or Canada where the national identity is interpenetrated with plural elements? After all, it must be remembered that all great empires established by the Ottomans or Austro-Hungary represented the expression of national identity in a political manner, exerting cooperation and co-independence, which, regardless of the fact that in quite an imposed way, created conditions for openness towards the Other. It seems that the paradox of Bosnian imponderables is included within "borderlines and political unity with simultaneous dialectics of constant disintegrating and unifying tendencies"(Stankowicz 2004, p. 38). 
In spite of the fact that most of theories tackling the issue of civilizational clashes are not applicable in the case of the specific, cultural identity of Bosnian Muslims, the power of external influence of separatist actions, taking advantage of particularly catchy idea of unified kalifat under the banner of not only Arabic but also European origin mustn't be marginalized.

\section{Bibliography}

Barber B.R. (1996), Jihad vs. McWorld: How Globalism and Tribalism Are Reshaping the World, Ballantine Books, New York.

Bellion-Jourdan J (1993), Les reseaux transmitionaux islamiques en Bosnie-Herzegovine, [in:] Bougarel X., Discour d'un Ramadan de guerre civile, „L'Autre Europe”, 26-27. Bougarel X. (1993), Discour d'un Ramadan de guerre civile, „L'Autre Europe”, 26-27. Buber M. (2004), I and Thou, Continuum, London \& New York.

Čuvalo A. (2007), Historical Dictionary of Bosnia and Herzegovina, Scarecrow Press, Plymouth.

Danecki J. (1997), Kultura Islamu, Wydawnictwa Szkolne i Pedagogiczne, Warszawa.

Elsässer J. (2008), Wie der Dschihad nach Europa kam : Gotteskrieger und Geheimdienste auf dem Balkan, Kai Homilius Verlag, Berlin.

Huntington S.P. (1996), The Clash of Civilizations and the Remaking of World Order, Simon \& Schuster, New York.

Ibrahimagić O. (1996), Bosna i Bošnjaci, Svjetlost, Sarajewo.

Kepel G. (2000), Jihad : expansion et déclin de l'islamisme, Gallimard, Paris.

Malcom N. (1994), Bosnia - a short history, MacMillan, London.

Parzymies A. (2005), Muzułmanie w Europie, Dialog, Warszawa.

Stankowicz A. (2004), Między bośniackościa a jugoslawizmem, Wyd. ATH, Bielsko-Biała. 